\title{
EFEK ANALGESIK INFUS DAUN TEKI (Cyperus rotundus L.) PADA MENCIT JANTAN (Mus musculus L.)
}

\author{
(ANALGESIC EFFECT OF TEKI LEAVES INFUSE (Cyperus rotundus L.) \\ ON MALE MICE (Mus musculus L.))
}

\author{
ERNA CAHYANINGSIH*, ELIS SUWARNI*
}

\author{
*Akademi Farmasi Saraswati Denpasar, Jalan Kamboja no. 11 A, Denpasar, Bali
}

\begin{abstract}
Abstrak: Telah dilakukan Uji Efek Analgesik Infus daun Teki (Cyperus rotundus L.) pada Mencit jantan (Mus musculus L.) menggunakan metode rangsang panas pada suhu $55^{\circ} \mathrm{C}$. Pada penelitian ini digunakan hewan uji berupa mencit jantan yang dibagi dalam lima kelompok masing-masing terdiri dari 6 ekor. Kelompok pembanding (asetosal), kelompok kontrol (aquades 0,5 ml), dan kelompok uji infus daun teki (infus 5\%, 10\%, 20\%). Data yang diperoleh dianalisis menggunakan metode Analisa Varian (ANOVA). Hasil penelitian menunjukkan bahwa terjadi peningkatan waktu munculnya respon pertama kali mencit menjilat kakinya pada kelompok yang diberi infus daun teki. Berdasarkan hasil penelitian dapat disimpulkan bahwa infus daun teki memiliki efek analgesik pada mencit.
\end{abstract}

Kata kunci: Analgesik, infus, daun Teki

\begin{abstract}
Have been done Analgesic Effect Test of Teki Leaves Infuse (Cyperus rotundus L.) on Male Mice (Mus musculus L.) use thermal stimulation method on temperature $55^{\circ} \mathrm{C}$. On this study use male mouse that separated on five groups, each group consist of six mices. The comparison group (asetosal), control group (aquades $0,5 \mathrm{ml}$ ) and the test group with teki leaves infuse (infuse 5\%,10\%,20\%). The data then analyzed with variant analysis method (ANOVA). The result showed there is an increase time when the first time the mice lick its leg on the group that given teki leaves infuse Based on this study can be concluded sedges infuse has analgesic effect on mice.
\end{abstract}

Keyword: Analgesic, infuse, teki leaves (Cyperus rotundus L.).

\section{PENDAHULUAN}

Indonesia merupakan Negara yang memiliki kekayaan hayati yang cukup besar yang dapat dikembangkan terutama untuk obat tradisional yang merupakan bahan atau ramuan bahan berupa bahan tumbuhan, bahan hewan, bahan mineral, sediaan sarian atau galenik, atau campuran dari bahan tersebut yang secara turun menurun telah digunakan untuk pengobatan berdasarkan pengalaman (Wasito, 2011).

Saat ini minat masyarakat untuk memanfaatkan kembali tumbuh-tumbuhan sebagai obat semakin meningkat, dikarenakan efek sampingnya yang relatif tidak ada. Salah satu tanaman yang dapat dimanfaatkan sebagai bahan obat tradisional adalah rumput teki, namun belum banyak masyarakat yang memanfaatkannya dikarenakan informasi ilmiah dan bukti manfaat yang menunjang masih kurang. Rumput Teki diduga mengandung flavonoid yang berpotensi untuk mengurangi rasa nyeri atau sebagai analgesik (Pandey dkk., 2013). Flavonoid merupakan salah satu dari sekian banyak senyawa metabolit sekunder yang dihasilkan oleh suatu tanaman, yang bisa dijumpai pada bagian daun, akar, kayu, kulit, tepung sari, bunga dan biji (Dani, 2012).

Analgesik adalah bahan atau obat yang digunakan untuk menekan atau mengurangi rasa sakit atau nyeri tanpa menyebabkan hilangnya kesadaran (Sumardjo, 2009 dalam Pandey dkk., 2013) Analgesik terbagi menjadi dua kelompok utama yaitu analgesik opioid dan analgesik non-opioid. Analgesik opioid merupakan kelompok obat yang selain memiliki efek analgesik, juga memiliki efek seperti opium (Gunawan, 2008 
dalam Pandey dkk., 2013). Analgesik opioid digunakan dalam penatalaksanaan nyeri sedang sampai berat (Price,2006 dalam Pandey dkk., 2013).

Nyeri adalah pengalaman sensorik dan emosional yang tidak menyenangkan yang berhubungan dengan adanya (aktual) atau potensi kerusakan jaringan atau keadaan yang menggambarkan kerusakan tersebut (Sukandar dkk., 2008). Nyeri dapat diklasifikasikan menjadi nyeri akut dan nyeri kronik berdasarkan lamanya nyeri. Nyeri dengan durasi sampai 7 hari yang biasanya terjadi secara mendadak disebut nyeri akut. Nyeri kronik adalah nyeri dengan durasi lebih dari 7 hari, bisa berbulan-bulan bahkan bertahuntahun (Ikawati, 2011 dalam Pandey dkk., 2013).

Penelitian yang telah dilakukan terhadap tanaman Rumput Teki (Cyperus rotundus L.) dari keluarga Cyperaceae menunjukkan Ekstrak Umbi Teki (Cyperus rotundus L.), Ekstrak Rumput Teki (Cyperus rotundus L.), dan Infus Akar Teki (Cyperus rotundus L.) memiliki efek analgesik (Dwi Sutiningsih, 2007; Pandey dkk., 2013; Puspitasari, Listyawati, dan Widiyani, 2003). Berdasarkan hal tersebut diatas, maka tujuan penelitian ini adalah akan dilakukan uji efek analgesik Infus daun teki (Cyperus rotundus L.) pada mencit (Mus musculus L.).

\section{BAHAN DAN METODE}

Rancangan Penelitian. Penelitian ini menggunakan rancangan percobaan yang berupa Rancangan Acak Sederhana dengan 5 macam perlakuan dan setiap unit perlakuan diulang sebanyak 6 kali, sehingga dibutuhkan 30 ekor mencit.

Bahan. Bahan yang digunakan untuk penelitian adalah infus daun teki (Cyperus rotundus L.) yang diperoleh darii Desa Pedungan, Denpasar, Bali. Pengambilan tanaman dilakukan pada tanggal 1 Januari 2015. Bahan lain yang digunakan untuk penunjang penelitian ini adalah asetosal sebagai pembanding dan aquadestilata sebagai kontrol yang diberikan secara oral.
Metode. Dalam pengujian efek analgesik digunakan hewan percobaan mencit putih jantan sehat berumur \pm 2 bulan pada saat perlakuan uji dengan bobot mencit 20-24g. Sebagai penginduksi nyeri digunakan hot plate, sebagai kontrol digunakan aquades dan bahan ujinya yaitu infus daun teki.

Prosedur penelitian. Mencit diadaptasi dengan lingkungan penelitian selama 10 hari. Tiga puluh mencit selanjutnya dikelompokkan menjadi 5 kelompok, masing-masing kelompok terdiri dari 6 ekor mencit. Masingmasing kelompok diberi perlakuan. Sebelum diberi perlakuan mencit sudah dipuasakan selama 6 jam tetapi tetap diberi minum, yaitu kelompok 1 sebagai kelompok kontrol hanya diberi aquades, kelompok 2 sebagai kelompok pembanding diberi asetosal 1,4 mg/21,9 $\mathrm{g}$ BB/ekor, kelompok 3, 4 dan 5 sebagai kelompok uji diberi infus daun teki dengan konsentrasi masing-masing 5\%,10\%, dan $20 \%$ - Semua perlakuan diberikan sebanyak 0,5 $\mathrm{ml} /$ ekor secara oral. Hewan didiamkan selama 15 menit untuk memberikan kesempatan distribusi obat ke dalam tubuh. Kemudian dilakukan pengujian dengan menggunakan metode induksi cara panas menggunakan alat hot plate dengan suhu $55^{\circ} \mathrm{C}$. Tiap mencit ditaruh diatas hot plate dengan suhu $55^{\circ} \mathrm{C}$. Kemudian stopwatch dihidupkan sampai mencit merasakan nyeri yang ditandai dengan gerakan menjilat kakinya. Dicatat waktu timbulnya respon nyeri pada mencit yaitu ketika pertama kali mencit menjilat kakinya.

\section{HASIL DAN PEMBAHASAN}

Hasil Uji Efek Analgesik Infus daun teki (Cyperus rotundus L.) Terhadap Mencit Jantan (Mus musculus L.).

Data hasil uji efek analgesik infus daun teki (Cyperus rotundus L.) pada mencit jantan yang diinduksi dengan cara panas terbagi menjadi 5 kelompok, yaitu data pada kelompok pembanding yang diberi Asetosal $0,5 \mathrm{ml}(1,4 \mathrm{mg})$, kelompok kontrol yang diberi Aquadest $0,5 \mathrm{ml}$. Masing-masing kelompok uji diberikan infus daun teki sebanyak $0,5 \mathrm{ml}$. Hasil pengamatan waktu pertama kali mencit jantan menjilat kakinya dapat dilihat pada tabel 1 . 
Tabel 1 Waktu Timbulnya Respon Nyeri (pertama kali mencit menjilat kakinya) pada Mencit Jantan Balb/C (Kelompok Pembanding, Kelompok Kontrol dan Kelompok Uji)

\begin{tabular}{|c|c|c|c|c|c|}
\hline \multirow[b]{3}{*}{ Mencit } & \multicolumn{5}{|c|}{ Waktu Timbulnya Respon Nyeri } \\
\hline & \multirow[b]{2}{*}{$\begin{array}{c}\text { Kelompok } \\
\text { Pembanding } \\
\text { Asetosal 0,5 } \\
\text { ml }\end{array}$} & \multirow[b]{2}{*}{$\begin{array}{c}\text { Kelompok } \\
\text { Kontrol } \\
\text { Aquadest } \\
\text { 0,5 ml }\end{array}$} & \multicolumn{3}{|c|}{ Kelompok Uji } \\
\hline & & & $\begin{array}{c}\text { Infus daun } \\
\text { teki } \\
\text { Konsentrasi } \\
5 \% 0,5 \mathrm{ml}\end{array}$ & $\begin{array}{c}\text { Infus daun } \\
\text { teki } \\
\text { Konsentrasi } \\
10 \% 0,5 \text { ml }\end{array}$ & $\begin{array}{c}\text { Infus daun } \\
\text { teki } \\
\text { Konsentrasi } \\
20 \% 0,5 \mathrm{ml}\end{array}$ \\
\hline 1 & 18 & 5 & 12 & 13 & 19 \\
\hline 2 & 15 & 9 & 11 & 15 & 10 \\
\hline 3 & 17 & 7 & 12 & 10 & 12 \\
\hline 4 & 10 & 7 & 13 & 14 & 18 \\
\hline 5 & 11 & 6 & 9 & 12 & 18 \\
\hline 6 & 19 & 8 & 10 & 11 & 9 \\
\hline $\begin{array}{l}\text { Rata- } \\
\text { rata }\end{array}$ & $\begin{array}{c}15 \text { detik } \pm \\
3.7417\end{array}$ & $\begin{array}{c}7 \text { detik } \pm \\
1.4142\end{array}$ & $\begin{array}{c}\text { 11,16 detik } \pm \\
1.4719\end{array}$ & $\begin{array}{c}\text { 12,5 detik } \pm \\
1.8708\end{array}$ & $\begin{array}{c}\text { 14,33 detik } \pm \\
4.5018\end{array}$ \\
\hline
\end{tabular}

\section{Analisis Data}

Data hasil pengujian selanjutnya di analisis menggunakan metode statistik (One
Way ANOVA). Hasil analisis data dapat dilihat pada tabel 2 .

Tabel 2 Anova: Aktivitas Analgesik Infus daun teki, Aquades dan Asetosal Waktu Timbulnya Respon Nyeri Mencit

\begin{tabular}{|l|r|r|r|r|r|}
\hline & Sum of Squares & \multicolumn{1}{c|}{ df } & Mean Square & F & \multicolumn{1}{c|}{ Sig. } \\
\hline Between Groups & 242.333 & 4 & 60.583 & 7.224 & .001 \\
Within Groups & 209.667 & 25 & 8.387 & & \\
Total & 452.000 & 29 & & & \\
\hline
\end{tabular}

Berdasarkan tabel anova diatas diperoleh nilai sig. anova $=0,001(\operatorname{sig} \alpha<0,05)$ yang dapat disimpulkan bahwa ada perbedaan waktu timbulnya respon nyeri antara kelompok pembanding, kelompok kontrol dan kelompok uji. Sedangkan pada tabel multiple comparison dapat diketahui ada atau tidaknya perbedaan rata-rata rangkaian data tiap kelompok yang dapat dilihat pada tabel .3.

\section{Tabel 3 Multiple Comparisons: Aktivitas Analgetik Infus daun teki, Aquadest dan Asetosal}

Dependent Variable: Waktu Timbulnya Respon Nyeri Mencit

\begin{tabular}{|c|c|c|c|c|c|c|c|}
\hline & \multirow[t]{2}{*}{$\begin{array}{c}\text { (I) } \\
\text { Kelompok }\end{array}$} & \multirow[t]{2}{*}{ (J) Kelompok } & \multirow{2}{*}{$\begin{array}{c}\text { Mean } \\
\text { Differen } \\
\text { ce }(\mathrm{I}-\mathrm{J})\end{array}$} & \multirow[t]{2}{*}{$\begin{array}{l}\text { Std. } \\
\text { Error }\end{array}$} & \multirow[t]{2}{*}{ Sig. } & \multicolumn{2}{|c|}{$\begin{array}{c}95 \% \text { Confidence } \\
\text { Interval }\end{array}$} \\
\hline & & & & & & $\begin{array}{l}\text { Lower } \\
\text { Bound }\end{array}$ & $\begin{array}{l}\text { Upper } \\
\text { Bound }\end{array}$ \\
\hline \multirow{2}{*}{$\begin{array}{l}\text { Tukey } \\
\text { HSD }\end{array}$} & $\begin{array}{l}\text { Kelompok } \\
\text { A }\end{array}$ & $\begin{array}{l}\text { Kelompok B } \\
\text { Kelompok C } \\
\text { Kelompok D } \\
\text { Kelompok E }\end{array}$ & $\begin{array}{l}8.000^{*} \\
3.833 \\
2.500 \\
.667\end{array}$ & $\begin{array}{l}1.672 \\
1.672 \\
1.672 \\
1.672 \\
\end{array}$ & $\begin{array}{l}.001 \\
.181 \\
.575 \\
.994\end{array}$ & $\begin{array}{l}3.09 \\
-1.08 \\
-2.41 \\
-4.24\end{array}$ & $\begin{array}{l}12.91 \\
8.74 \\
7.41 \\
5.58\end{array}$ \\
\hline & $\begin{array}{l}\text { Kelompok } \\
\text { B }\end{array}$ & $\begin{array}{l}\text { Kelompak A } \\
\text { Kelompok C } \\
\text { Kelompok D } \\
\text { Kelompok E }\end{array}$ & $\begin{array}{l}-8.000^{*} \\
-4.167 \\
-5.500^{*} \\
-7.333^{*}\end{array}$ & $\begin{array}{l}1.672 \\
1.672 \\
1.672 \\
1.672\end{array}$ & $\begin{array}{l}.001 \\
.125 \\
.023 \\
.002\end{array}$ & $\begin{array}{l}-12.91 \\
-9.08 \\
-10.41 \\
-12.24\end{array}$ & $\begin{array}{l}-3.09 \\
.74 \\
-.59 \\
-2.42\end{array}$ \\
\hline
\end{tabular}


Dependent Variable: Waktu Timbulnya Respon Nyeri Mencit

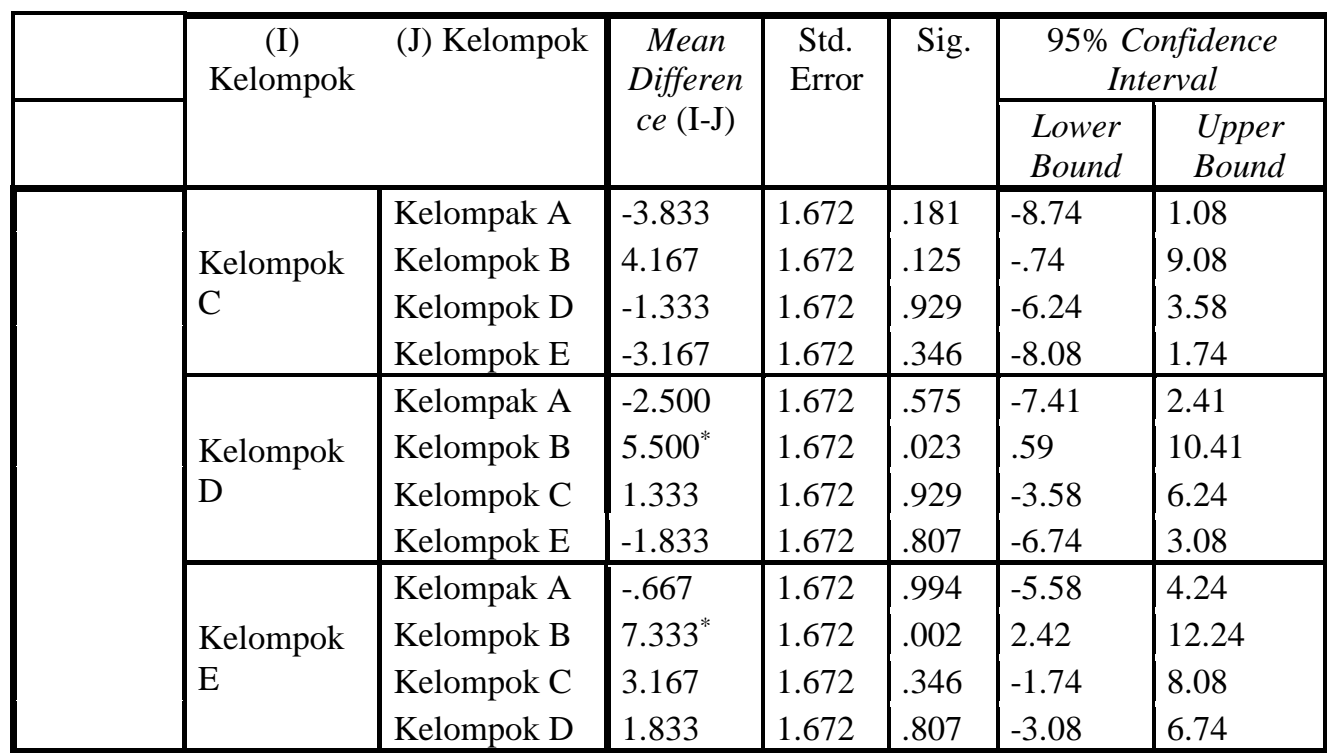

Keterangan:

*. The mean difference is significant at the 0.05 level.

Kelompok A: Kelompok pembanding (Asetosal)

Kelompok B : Kelompok kontrol (Aquades)

Kelompok C : Kelompok uji (Infus daun teki konsentrasi 5\%)

Kelompok D : Kelompok uji (Infus daun teki konsentrasi 10\%)

Kelompok E : Kelompok uji (Infus daun teki konsentrasi 20\%)

Data hasil uji efek analgesik dianalisis menggunakan metode Analisa Varian (ANOVA) untuk mengetahui ada atau tidaknya perbedaan waktu timbulnya respon nyeri antara kelompok pembanding (asetosal), kelompok kontrol (aquades) dan kelompok uji (infus 5\%, 10\%, 20\%). Hasil penelitian menunjukkan nilai Sig. $\mathrm{F}=0,001$ (tabel 2) yang berarti bahwa ada perbedaan waktu timbulnya respon nyeri mencit jantan antara kelompok pembanding (asetosal), kelompok kontrol (aquades) dan kelompok uji (infus 5\%, $10 \%, 20 \%)$

Selanjutnya berdasarkan metode HSD (High Significant Design) test menggunakan Tuckey test untuk mengetahui ada atau tidaknya perbedaan rata-rata rangkaian data tiap kelompok, berdasarkan tabel 3 Multiple Comparisons antara kelompok pembanding (asetosal) dengan kelompok kontrol (aquades) diperoleh nilai $\mathrm{Sig} F=0,001$ yang menunjukkan bahwa ada perbedaan bermakna antara kelompok pembanding dengan kelompok kontrol. Hasil perbandingan antara kelompok pembanding (asetosal) dengan kelompok uji (infus 5\%, 10\% dan 20\%) diperoleh nilai Sig $\mathrm{F}$ masing-masing yaitu: $0,181,0,575$, dan 0,994 yang menunjukkan bahwa tidak ada perbedaan bermakna antara kelompok pembanding dengan kelompok uji.
Hasil kelompok kontrol (aquades) dengan kelompok uji (infus daun teki konsentrasi 5\%) diperoleh nilai Sig F $=0,125$ yang menunjukkan bahwa tidak ada perbedaan bermakna antara kelompok kontrol (aquades) dengan kelompok uji (infus 5\%) sedangkan dengan kelompok uji (infus 10\% dan 20\%) diperoleh nilai Sig $\mathrm{F}$ masing-masing yaitu: 0,023 dan 0,002 yang berarti bahwa ada perbedaan bermakna antara kelompok kontrol (aquades) dengan kelompok uji (infus 10\% dan 20\%).

Selanjutnya hasil perbandingan antara kelompok uji (infus 5\%, 10\% dan 20\%) menunjukkan bahwa tidak ada perbedaan bermakna antara sesama kelompok uji. Berdasarkan penjelasan tersebut dapat diketahui bahwa infus daun teki memiliki efek analgesik pada mencit. Hal ini dikarenakan adanya senyawa flavonoid yang berpotensi untuk mengurangi rasa nyeri atau sebagai analgesik yang terdapat pada umbi rumput Teki (Gemilang, 2013). Flavonoid merupakan salah satu dari sekian banyak senyawa metabolit sekunder yang dihasilkan oleh suatu tanaman, yang bisa dijumpai pada bagian daun, akar, kayu, kulit, tepung sari, bunga dan biji (Dani, 2012). 


\section{SIMPULAN}

Berdasarkan hasil penelitian dapat disimpulkan bahwa infus daun teki (Cyperus rotundus $L$.) memiliki efek analgesik pada mencit jantan (Mus musculus L.)

\section{DAFTAR PUSTAKA}

Dani, F. R. 2012, Potensi Ekstrak Umbi Teki ( Cyperus Rotundus L .) Dalam Menurunkan Jumlah Limfosit Jaringan Granulasi Setelah Pencabutan Gigi Tikus Wistar Jantan, Skripsi, Fakultas Kedokteran Gigi,Universitas Jember, Jember.

Dwi Sutiningsih, M. 2007, Studi Eksperimental Efek Analgetik Infus Akar Teki (Cypemalynerus Rotundus Linn) Pada Hewan Coba (Mencit), diakses pada tanggal 5 juli 2015, $<$ http://download.portalgaruda.org/article. php? article $=4672 \&$ val $=431>$.

Gemilang, J. (2013). Khasiat Selangit DaunDaun \& Buah-Buah Ajaib Tumpas
Beragam Penyakit Berbahaya. (W. T., Ed.). Yogyakarta: Araska.

Pandey, P. V., Bodhi, W., \& Yudistira, A. 2013, Uji Efek Analgetik Ekstrak Rumput Teki ( Cyperus rotundus L .) Pada Tikus Putih Jantan Galur Wistar ( Rattus Novergicus ), Pharmacon Jurnal Ilmiah Farmasi-UNSRAT, 2(02): 2302-2493 diakses pada 20 Januari 2015, http://ejournal.unsrat.ac.id/index.php/phar macon/article/viewFile/1579/1271.

Puspitasari, H., Listyawati, S., \& Widiyani, T. 2003, Aktivitas Analgetik Ekstrak Umbi Teki ( Cyperus rotundus L.) Pada Mencit Putih ( Mus Musculus L .) Jantan, diakses pada tanggal 6 Juli 2015, <http://biosains.mipa.uns.ac.id/F/F0102/ F010203.pdf $>$.

Sukandar, E. Y., Andrajati, R., Sigit, J. I., Adnyana, I. K., Setiadi, A. A. P., \& Kusnandar. 2008, ISO Farmakoterapi, Jakarta: Pt. Isfi Penerbitan.

Wasito, H. 2011, Obat Tradisional Kekayaan Indonesia, Graha Ilmu, Yogyakarta. 